\title{
Sykepleierstudenter må læere å samarbeide på tvers av profesjoner
}

Hvis studentene skal utvikle samarbeidskompetanse, må veiledere, praksislærere og studenter utnytte tverrprofesjonelle læresituasjoner.

\section{Bente Kvilhaugsvik}

Førstelektor

Institutt for helse- og omsorgsvitskap, Høgskulen på Vestlandet

\section{Synnøve Hofseth Almås}

Dosent emerita

Institutt for helsevitenskap, Norges teknisk-naturvitenskapelige universitet

\begin{tabular}{|l|l|l|l|l|l|l|}
\hline Sykepleierstudent Teamarbeid & Tverprofesjonell samarbeidslæring \\
\hline
\end{tabular}

\section{Hovedbudskap}

Sykepleierstudenter må lære sykepleieferdigheter, men de må også bli gode samarbeidspartnere. Denne artikkelen bygger på et fokusgruppeintervju med studenter som hadde praksis i en vestlandskommune. Kommunen satset på tverrprofesjonelt teamarbeid, og studentene fikk mange muligheter til å lære teamferdigheter sammen med helsepersonell fra andre profesjoner.

Ifølge statlige føringer $(1,2)$ skal studenter på helse- og sosialfaglige profesjonsutdanninger lære å samarbeide tverrprofesjonelt. Læringen skal fortrinnsvis foregå i praksisfeltet. 
Målet er at studentene skal utvikle tverrprofesjonell samhandlingskompetanse. Dette innebærer en forståelse av egen og andre profesjoners roller, tverrprofesjonell kommunikasjon, verdien i og av tverrprofesjonelt arbeid, evnen til å koordinere og fatte beslutninger i fellesskap, evnen til å reflektere og ulike aspekter ved teamarbeid (3, 4). Det å tilegne seg denne kompetansen kalles tverrprofesjonell samarbeidslæring (TPS) (3).

Som fremtidige profesjonsutøvere må studentene forstå sin rolle som en del av velferdssystemet og utvikle sin profesjonelle identitet i tråd med det (5). Med andre ord må grunnutdanningene innen helse- og sosialfagene stimulere til utvikling av både profesjonsidentitet og identitet som velferdsarbeider (6).

Denne artikkelen viser at TPS i praksisperioder førte til at studentene utviklet samarbeidskompetanse. De ble mer bevisste på behovet og premisser for tverrprofesjonelt samarbeid og læring.

\section{Læring forutsetter refleksjon}

Norske universiteter og høyskoler, i samarbeid med praksisfeltet, arbeider med å implementere TPS i teoretiske og praktiske deler av helse- og sosialfagutdanningene. Vår erfaring er at noen kommuner har kommet langt med å legge til rette for at profesjonsstudentene skal lære å samarbeide når de er der i praksis, mens andre kommuner ikke har kommet like langt.

\section{«En måte å lære om andre profesjoner på er at studenter skygger helsepersonell.»}

Studenter konstruerer læring i sosiale rammeverk. I litteraturen om TPS understrekes det at TPS innebærer læring, og at læring forutsetter refleksjon (8). En måte å lære om andre profesjoner på er at studenter skygger eller observerer helsepersonell. Da kan de få kunnskap om ulike profesjoners ansvarsområder og bli oppmerksomme på behovet for tverrprofesjonelt samarbeid (9). 


\section{Praksiskommunen satset på team}

I artikkelen beskriver vi resultatene fra et fokusgruppeintervju med fire sykepleierstudenter, en mann og tre kvinner mellom 20 og 35 år. Studentene hadde tredje praksisperiode i en kommune i Vestland fylke våren 2019.

Teamarbeid er et satsingsområde i kommunen.

Studentene var i sykehjems- og hjemmesykepleieavdelinger og fikk muligheten til å ha observasjonspraksis. I avdelinger som hadde knyttet til seg flere spesialiserte team, fikk studentene observere ulike

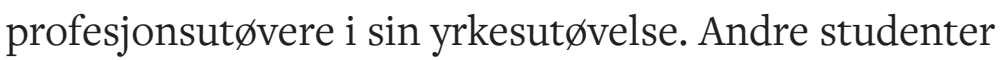
hospiterte på legevakten eller i ambulansetjenesten.

Fokusgruppeintervju ble valgt som datainnsamlingsmetode fordi man i slike intervjuer får frem respondentenes ulike synspunkter i tillegg til interaksjoner mellom dem (10). I analysen brukte vi Lindseth og Norbergs fenomenologisk-hermeneutiske metode (11), som er en god metode når man vil dele inn dataene fra et kvalitativt intervju i temaer og undertemaer.

De fire studentene hadde erfaringer fra praksis i en kommunal rehabiliteringsavdeling, en subakutt medisinsk sykehjemsavdeling, demensomsorg og hjemmesykepleie, i tillegg til blant annet legevakt, ambulanse og et hverdagsrehabiliteringsteam i åpen omsorg.

Dette var temaene som fremkom gjennom analysen av intervjuene:

1. Studentene fikk økt oppmerksomhet på at de skulle lære å samarbeide tverrprofesjonelt.

2. Innsyn i tverrprofesjonelt arbeid førte til innsikt i behovet for teamarbeid.

3. Nødvendige forutsetninger må være til stede for å kunne gjennomføre TPS. 


\section{Studentene fikk økt oppmerksomhet på at de skulle lære å samarbeide tverrprofesjonelt}

Studentene identifiserte mulige læresituasjoner og sa at de lærte både fra ansatte i praksisavdelingene og av å diskutere med hverandre. Noe av læringen skjedde ved at de ble klar over at forskjellige personer vurderte samme situasjon ulikt.

Studentene uttrykte at selv én dags praksis med observasjon av en annen profesjon med komplementær kompetanse ga læringsutbytte.

\section{Forståelse er en forutsetning for samarbeid}

For å forstå hvordan de skulle bruke sin egen profesjonskompetanse i samspill med andres, mente studentene at de måtte sette seg inn i hvordan helsepersonell fra andre profesjoner kartla og vurderte situasjoner. En student sa: «Vi studenter har delt erfaringer og opplevelser med hverandre når vi har kommet opp i situasjoner. Jeg kan tolke en situasjon litt annerledes enn de andre» (S2).

Men det var ofte lite tid for studentene til å observere andres profesjonsutøvelse. Noen fikk kun være med på noen timer en fysioterapeut hadde med pasienter. Denne begrensede innføringen i fysioterapeutens arbeidsmåter gjorde studentene mindre motivert for samarbeidslæring. Når de derimot fikk mulighet til å sette seg inn i hvordan man resonnerte $\mathrm{i}$ andre profesjoner, ble studentene mer motivert til å samarbeide med helsepersonell fra den profesjonen.

En student fikk være en dag på legevakten. Hen mente at dagen hadde gitt innsikt i å legge til rette for godt samarbeid med legevaktpersonell og hvilken informasjon man i legevakten trenger fra sykepleiere.

Hen understreket følgende: «Det er stor forskjell på å skaffe seg erfaring fra en telefonsamtale med de som sitter der, og det å få lov til å sitte i andre enden og se hvordan ting fungerer. På legevakten ser de jo ingen mennesker, de sitter og ser inn i tre skjermer» $\left(\mathrm{S}_{3}\right)$. 
En annen student hadde lært ved å formidle informasjon mellom kontaktsykepleier og legevakt. Hen sa: «Jeg lærte mye av å ta telefonen til legevakten og formidle situasjonen, og så ringe til sykepleier igjen om hva legen hadde sagt. Det er viktige avgiørelser som skal tas» (S2). Studentene var enige om at det å skulle beskrive et klinisk bilde med ord ikke var enkelt.

\section{Studentene må ta initiativ selv}

Studentene hadde inntrykk av at kontaktsykepleierne primært var opptatt av sine egne arbeidsoppgaver og å lære studentene det deres jobb innebar. Det var derfor ikke sentralt for kontaktsykepleierne å lete etter mulige tverrprofesjonelle læresituasjoner, men studentene og praksislæreren fra utdanningsinstitusjonen brakte temaet på banen.

En student poengterte: «Jeg opplevde det som litt tilfeldig, men hvis jeg brakte tema om samarbeidssituasjoner på bordet, var det aktuelt å få være med» (S4).

\section{«Det er noe med å bare hoppe i det.»}

\section{Sykepleierstudent}

Studentene måtte utfordre seg selv til å ta initiativ til tverrprofesjonelt samarbeid. En student formulerte det slik: «Det er noe med å bare hoppe i det. Og kontaktsykepleieren kan være i nærheten, så skulle det gå skeis, er det ikke verre enn at en gir telefonen til kontaktsykepleier» (S3).

En student sa følgende: «Jeg var på kirurgisk avdeling $\mathrm{i}$ andre praksis og fikk vært med på litt av hvert. Jeg hadde veldig godt utbytte av det» (S2).

\section{Innsyn i tverrprofesjonelt arbeid førte til innsikt i behovet for teamarbeid}

Tilknyttet hjemmetjenesten i den aktuelle kommunen var det etablert tverrprofesjonelle team. Et par studenter hadde vært i kontakt med hverdagsrehabiliteringsteamet, der ergoterapeut, fysioterapeut, helsefagarbeider og sykepleier deltok. 
Andre tverrprofesjonelle settinger oppsto i de forskjellige samarbeidsrelasjonene mellom kommunale sykehjemsavdelinger, hjemmetjeneste, legevakt og ambulansetjeneste.

\section{Ulike avdelinger har ulike systemer}

Noen studenter fikk mulighet til å hospitere i et hverdagsrehabiliteringsteam. For å lære å samarbeide godt $\mathrm{i}$ teamet mente studentene at de trengte å bli kjent med rammene for avdelingens system. Et eksempel på det kunne være at pasienten må søke om hverdagsrehabilitering via forvalterkontoret.

Studentene lærte om premisser for det tverrprofesjonelle samarbeidet og hvordan teamet laget planer for pasientene. Informantene sa at det kreves en ekstra innsats i starten av et teamarbeid i form av at profesjonsut Øverne må ta seg tid til å snakke sammen. Men teamarbeid giør samtidig at man kan spare ressurser i etterkant.

Studentene erfarte at hverdagsrehabiliteringsteamet hadde et opplæringsansvar for hjemmetjenestens personale. De mente at arbeidet som legges ned i hverdagsrehabilitering, sparer hjemmesykepleien for mye arbeid, og at det er viktig at de to avdelingene samarbeider godt.

En student påpekte at «hverdagsrehabiliteringen lærte opp ... sykepleiere hjemme hos pasienter» (S1). Studentene mente at personalet $\mathrm{i}$ avdelingene fikk innsyn $\mathrm{i}$ hverandres tenkning gjennom samarbeidet.

Hverdagsrehabiliteringsteamet, der det var fysioterapeuter og ergoterapeuter i tillegg til sykepleiere, ble bedt om hjelp til å etablere ergonomiske forflytningsteknikker og hensiktsmessige arbeidsformer hos brukere.

En av studentene hadde bakgrunn som paramedic og arbeidet $i$ ambulansetjenesten. Gjennom samtaler med denne studenten og muligheten til å være med $\mathrm{i}$ ambulansen på dager hen jobbet der, fikk de andre studentene innblikk i hvordan ambulansepersonell arbeider, og premisser for godt samarbeid med dem. 
Studenten som arbeidet i ambulansetjenesten, og som nå tok sykepleierutdanning, var på vei til å få en dobbel fagidentitet, noe som gjorde at vedkommende fikk enda større forståelse for hvordan ulike tjenester henger sammen.

Dagene i ambulansetjenesten kan være ekstra travle. Studenten sa: «Dere var med på travle dager der en ser at en skulle ha samarbeidet mer, og brukt mer tid, men det kan vi ikke. Vi har noe på vent, og så må vi gjerne bearbeide noe av det vi har gjort selv» (S4).

\section{Tverrprofesjonelt samarbeid kan frigjøre tid}

Studentene opplevde ikke at TPS og læring av sykepleiefaget var to atskilte fenomener, men at det ga merverdi å gå inn i begge deler samtidig. Studenten som hadde fått være en dag på legevakten, understreket følgende: «Jeg synes ikke at TPS har tatt for mye tid. Jeg har vært på legevakten i en dag, har fått være med på et par tverrfaglige møter og har vært litt med en fysioterapeut. Men det har ikke tatt noe fra det andre» (S3).

\section{«Hverdagsrehabiliteringen har teknikker som gjør at det går helt fint å være én.»}

\section{Sykepleierstudent}

Når de fikk mulighet til å møte samme pasient i flere ledd av en behandlingskjede, visste studentene hvilken informasjon pasienten hadde fått underveis, hva som var blitt gjort, og hva som det måtte tas hensyn til videre. På den måten mente studentene at de lærte å ivareta sykepleiefunksjonen på en helhetlig måte.

Studentene uttrykte at det å lære av utøvere av andre profesjoner kan være effektivt. Et eksempel fra en student var: «Hjemmesykepleien kom til en pasient de syntes var tung og de måtte være to, mens hverdagsrehabiliteringen har teknikker som gjør at det går helt fint å være én» (S1). Slik kan tid frigjøres. 


\section{Nødvendige forutsetninger må være til stede for å kunne gjennomføre TPS}

For at TPS skal være mulig, må det tilrettelegges for det. I noen avdelinger var det lite tverrprofesjonelt samarbeid. Det at praksislærer etterspurte TPS i begynnersamtaler og midtevaluering, gjorde det lettere for både studenter og kontaktsykepleiere å rettferdiggjøre å sette av tid til samarbeidslæring.

\section{Samarbeid var ikke like naturlig overalt}

Studentene opplevde situasjoner der samarbeidet fungerte godt, og situasjoner der de mente samarbeidet kunne vært bedre. Noen profesjoners kompetanser var ikke like tilgjengelige i sykehjem som i hjemmetjenesten.

Et eksempel var at en student savnet en fysioterapeuts kompetanse om å motvirke kontrakturer hos personer med demens. Fysioterapeutene var lite til stede $\mathrm{i}$ avdelingen og ble i liten grad konsultert. Personalgruppen hadde fått innføring i arbeidsteknikker som kunne brukes, men studenten savnet en dialog med fysioterapeuten om aktuelle problemstillinger.

Hen sa: «Jeg hadde ønsket å være sammen med fysioterapeuten litt lenger, og ikke bare få en instruks ... Jeg hadde likt å få forklart bakenforliggende årsaker til problemstillinger og hva vi kan gjøre» (S4).

Studentene mente at hvorvidt man arbeider tverrprofesjonelt $\mathrm{i}$ en avdeling, har å gjøre med avdelingens oppgaver: «Om man er på en avdeling type livsglede eller lindrende behandling, er jo ikke fysioterapi det som er fokuset» (S3).

I hjemmetjenesten var det et $\varnothing$ nske om at pasienter skulle bo lengst mulig hjemme, og de ansattes kompetanser var rettet inn mot å oppnå det. Der var tverrprofesjonelt samarbeid en naturlig del av virksomheten, og studentene ble inkludert i dette.

\section{Organisering er en premiss for TPS}


For at studenter som hadde yrkeserfaring fra

helsetjenesten, skulle lære nye ting, mente studentene at sykepleierne og praksislæreren måtte etterspørre hva de kunne fra før. En student som jobbet i hjemmesykepleien i helger, mente følgende: «Jeg hadde mye igjen for å være inne på kontoret en dag sammen med lederen og lage arbeidslister og se hvordan organiseringen er, svare i telefonen og delegere arbeid» (S2).

\section{«Delte stillinger kan bidra til kontinuitet $\mathbf{i}$ arbeidsformer på tvers av avdelinger.»}

Slik individuell tilrettelegging ga organisatorisk læring. Studentene så generelt på god organisering av arbeidet i avdelingene som en premiss for teamsamarbeid og TPS, fordi de da lettere fikk oversikt over behov og muligheter.

Kontaktsykepleierne hadde en viktig rolle i å gi studentene tverrprofesjonelle læringsmuligheter. Noen kontaktsykepleiere hadde delte stillinger, for eksempel 50 prosent i hjemmetjenesten og 50 prosent $i$ hverdagsrehabiliteringsteamet. Det kan bidra til kontinuitet $\mathrm{i}$ arbeidsformer på tvers av avdelinger.

Studentenes opplevelse var at dette i tillegg bidro til gode hospiteringsmuligheter.

\section{Profesjonell selvinnsikt er viktig}

I denne studien har vi unders $\varnothing \mathrm{kt}$ sykepleierstudenters opplevelse av TPS i praksis. Resultatene viser at studentene som deltok i TPS, ble oppmerksomme på at en av målsettingene med praksisperioden var å lære å samarbeide på tvers av profesjonsgrenser. De fikk innsyn i behovet for denne typen samarbeid og hvilke premisser som ligger til grunn for å gjennomføre TPS.

Læring av samarbeidskompetanse skjer ikke av seg selv (3, 6). Både utdanningsinstitusjonene og praksisavdelingene er en del av et utdanningskontinuum og har begge ansvar for studentenes læring. (12). I en travel hverdag er det likevel lett å falle tilbake til profesjonenes etablerte arbeidsvaner (13). Det at TPS ble aktualisert av praksislæreren, og at kontaktsykepleierne støttet dette, var en av premissene for at studentene kunne forsvare å bruke tid til tverrprofesjonell samarbeidslæring. 


\section{«Å ha innblikk i sin egen profesjonelle rolle er en viktig del av den tverrprofesjonelle kompetansen.»}

Som vi har sett, innebærer samarbeidskompetanse å kombinere rolleforståelse med en evne til tverrprofesjonell kommunikasjon (3). Det at studentene var årvåkne om at personer fra ulike profesjoner ser forskjellig på situasjoner, støtter nettopp det. Å ha innblikk i sin egen profesjonelle rolle er en viktig del av den tverrprofesjonelle kompetansen (4).

Studentene hospiterte hos ulike typer helsepersonell og i forskjellige avdelinger, og reflekterte over egen og andre profesjoners perspektiver og arbeidsformer $\mathrm{i}$ samarbeidssituasjoner. Studenten som fikk innsyn i legevaktarbeid ved å hospitere der i en dag, lærte om komplementære roller og om kommunikasjon med legevaktpersonell. Læringsverdien av en slik skyggepraksis er godt dokumentert i tidligere studier (9).

TPS handler om læring, og læring krever refleksjon (8) og er en kontinuerlig og skiftende prosess (14). Studentene var opptatt av det tverrprofesjonelle samarbeidet og hvordan de kunne $\varnothing$ ke sin kompetanse på det. De reflekterte og diskuterte sammen om temaer som det å veksle mellom ulike perspektiver.

På den måten ble evnen til å reflektere over samarbeidssituasjoner (3) Øvet opp, slik at studentene etter hvert både observerte behov for samarbeid, premisser for sin egen motivasjon for samarbeid og mulige situasjoner der de kunne $\varnothing$ ke sin erfaring og kunnskap.

Når studentene sa at TPS styrket, og ikke tok noe ifra, den sykepleiefaglige læringen i praksis, kan det handle om utviklingen av sykepleieridentitet. Både utdanningen, personligheten og erfaringene studentene får i praksis, er med på å forme deres identitet som profesjonelle sykepleiere, som samtidig ser på seg selv som en av profesjonsgruppene i velferdsstaten (6). 


\section{Tillit må man øve på}

Studentene fremhevet at man må ha en viss trygghet på egne profesjonsferdigheter før man utfordrer disse i møte med utøvere av andre profesjoner. Tryggheten som poengteres, handler trolig om trygghet både på seg selv og på andre, og er nært knyttet til kommunikasjon.

Tverrprofesjonell kommunikasjon henger sammen med det å kunne etablere tillitsfulle relasjoner til ulike samarbeidsparter. Det handler om å se mangfold og ulikhet mellom profesjoner og avdelinger som styrker, og ikke som trusler mot samarbeid (15). Dette både kan og må man øve på, som en del av den tverrprofesjonelle samarbeidslæringen.

Studentene som ble veiledet av hverdagsrehabiliteringsteamet, fikk erfare hvordan verdien om å bo lengst mulig hjemme førte til felles arbeidsmåter mellom teamet og hjemmesykepleien. Dette handler om koordinering og teamarbeid (3). Studentene sa at samarbeidet ga profesjonene og avdelingene innsyn i hverandres tenkning, noe som gjør det enklere å etablere felles mål og arbeidsmåter (7).

\section{«Strukturene i helsetjenestens organisasjoner må støtte tverrprofesjonelt samarbeid.»}

Behandlingskjeden handler om alle behandlingsleddene en pasient er innom $(1,7)$. Sykepleierstudentene møtte noen ganger samme pasient i flere ledd av en behandlingskjede, slik som hjemmesykepleie, legevakt, ambulanse og sykehjemsavdeling. Når studentene visste hvilken informasjon pasienten hadde fătt, og hva som var blitt gjort og måtte tas hensyn til videre, mente de at de kunne gi bedre sykepleie til pasienten.

Strukturene i helsetjenestens organisasjoner må støtte tverrprofesjonelt samarbeid og TPS $(7,16)$. I noen av avdelingene studentene hadde praksis $i$, var organiseringen av tjenestene tverrprofesjonell. Dette påvirket mulighetene til TPS. 
Studentene mente at dette angår avdelingenes ansvarsområder. Vestlandskommunen i denne studien hadde imøtekommet kravene til koordinerte tjenester, noe som også kom sykepleierstudentene til gode når de skulle lære om samhandling og tverrprofesjonelt samarbeid i praksis.

\section{Læresituasjoner må utnyttes}

Det at studenter observerer og samarbeider med ferdig utdannet helsepersonell fra andre profesjoner, synes å gi både samarbeidskompetanse og innsyn $\mathrm{i}$ behovet for samarbeid på tvers av profesjonsgrenser.

I denne studien fant vi to viktige premisser for at studenter og kontaktsykepleiere skal rettferdiggjøre å sette av tid til samarbeidslæring: Avdelingene må ha organisatoriske og pedagogiske rammer som gir rom for at studentene får trene på samarbeid. Og studenter, veiledere i praksis og praksislærere må være bevisste på å utnytte mulige tverrprofesjonelle læresituasjoner.

\section{Referanser}

1. St.meld. nr. 47 (2008-2009).

Samhandlingsreformen. Rett behandling - på rett sted - til rett tid. Oslo: Helse- og omsorgsdepartementet; 2009.

2. $\quad$ Forskrift 6. september $2017 \mathrm{nr}$. 1353 om felles rammeplan for helse- og sosialfagutdanninger. Tilgjengelig fra: https://lovdata.no/dokument/SF/forskrift/2017-09-06$\underline{1353}$ (nedlastet 07.04.2021).

3. Iversen A, Hauksdottir N. Tverrprofesjonell samhandling - en kompetanse som må læres. I: Iversen A, Hauksdottir N, red. Tverrprofesjonell samhandling og teamarbeid. Kjernekompetanse for fremtidens helse- og velferdstjenester. Oslo: Gyldendal Norsk Forlag; 2020.

4. Walsh CL, Gordon MF, Marshall M, Wilson F, Hunt T. Interprofessional capability: a developing framework for interprofessional education. Nurse Educ Pract. 2005;5(4):230-7.

5. Meld. St. 13 (2011-2012). Utdanning for velferd.

Oslo: Kunnskapsdepartementet; 2012. 
6. Almås SH, Dahl BM. Identitet. I: Almås SH, Vasset

F, Ødegård A, red. Tverrprofesjonell samarbeidslæring (TPS) - for bachelorstudenter i helse- og sosialfag. Bergen:

Fagbokforlaget; 2018.

7. Kvilhaugsvik B, Hus $\varnothing y$ G. Må samarbeide mer på tvers. Sykepleien. 2017;105(3):64-7. Tilgjengelig fra:

https://sykepleien.no/forskning/2017/02/ma-samarbeidemer-pa-tvers (nedlastet 07.04.2021).

8. Clark PG. Reflection on reflection in interprofessional education: implication for theory and practice. J Interprof Care. 2009;23(2):54-66.

9. Vasset F, Almås SH. Shadowing: interprofessional learning. Journal of Research in Interprofessional Practice and Education. 2015;5(2).

10. Malterud K. Fokusgrupper som forskningsmetode for medisin og helsefag. Oslo: Universitetsforlaget; 2012.

11. Lindseth A, Norberg A. A phenomenological hermeneutical method for researching lived experience. Scand J Caring Sci. 2004;18(2):145-53.

12. Universitets- og høyskolerådet. Kvalitet i praksisstudiene i helse- og sosialfaglig høyere utdanning: praksisprosjektet. Sluttrapport fra et nasjonalt utviklingsprosjekt gjennomført på oppdrag fra KD i perioden 2014-2015. Oslo: Universitets- og høyskolerådet; 2016. Tilgjengelig fra:

https://www.regjeringen.no/contentassets/86921ebe6f4c45d9a2f67fdaze6eaeo8/praksisprosjektetsluttrapport.pdf (nedlastet 07.04.2021).

13. Hall P. Interprofessional teamwork: professional cultures as barriers. J Interprof Care. 2005;19(Suppl 1):188-96.

14. Bærheim A, Hauksdottir N, Iversen A. Refleksivitet og refleksjon. I: Iversen A, Hauksdottir N, red. Tverrprofesjonell samhandling og teamarbeid. Kjernekompetanse for fremtidens helse- og velferdstjenester. Oslo: Gyldendal Norsk Forlag; 2020. 
15. Brenna S, Kvilhaugsvik B, Hauksdottir N. Verdier i profesjonell og tverrprofesjonell samhandling. I: Iversen A, Hauksdottir N, red. Tverrprofesjonell samhandling og teamarbeid. Kjernekompetanse for fremtidens helse- og velferdstjenester. Oslo: Gyldendal Norsk Forlag; 2020.

16. Almås SH, Vasset F. Rammer. I: Almås SH, Vasset F, $\varnothing$ degård A, red. Tverrprofesjonell samarbeidslæring (TPS) - for bachelorstudenter i helse- og sosialfag. Bergen:

Fagbokforlaget; 2018. 